theme 5

society

author(s) strand 2

design activism
Marja Seliger marja.seliger@aalto.fi

Aalto University
Blucher Design Proceedings Dezembro de 2014, Número 5, Volume 1

\title{
Visual Rhetoric in Design Activism
}

The study investigates visual rhetoric through literary review and two case studies. Visual rhetoric is understood as argumentation and persuasion using pictorial symbols and images. The on-line media allow multimodal communication and invite people to participate in public debates as activators or supporters. Today anyone can reach global audiences by posting pictures and messages in Internet.

The concept of vividness of information is introduced to analyse visual rhetoric in communication. Vivid information can cause strong emotional reactions, whereas lessvivid information causes more analytical responses. The study shows emotional reactions caused by political cartoons. When visuals are distributed globally, interpretations multiply and reactions become controversial.

The art of rhetoric includes also logical reasoning and convincing audiences with facts. In visual rhetoric that means using less-vivid information, e.g. graphs to visualize numerical information. For design activism on-line communication facilitates interactivity, participatory actions, co-designing events and collaboration. When knowing the rules and ethics of global communication it seems that on-line platforms give versatile possibilities for design activism. visual rhetoric, communication design, political cartoon, argumentation, persuasion

\section{Introduction}

The definition of design activism today stands for responsible design. For communication designers responsibility signifies informing, explaining and activating people to participate in design actions and to improve present conditions in local and global communities. The methods used for activating citizens have changed from oral and verbal rhetoric towards visual communication in media and environments. As the amount of information increases, the challenging task for designers is to find the most effective visual language and expressions for each communication case.

The transitions in communication modes and media have generated growing interest in visual rhetoric studies (e.g. Hill and Helmers 2004; Olson, Finnegan and Hope 2008). Gronbeck cites Jay and uses the word ocularcentric to describe the expanding use of visual media: "Because of the explosion of mediated spectacle and the public's seemingly insatiable hunger for it, the 19th and 2oth century in West have been called ocularcentric (Jay, 1994), or eye centred" (Gronbeck 2008: xxi). He emphasizes the role of posters as a medium for political communication and their ability to call citizens for participatory actions, whereas Navasky (2013) analyses political cartoons. 
During the 2oth century media industry multiplied the use of images in communication. Olson et al. argue that our contemporary period is not unique in being dominated by images: "[...] in every historical period, images have been an influential presence in the public sphere. Public images often work in a ways that are rhetorical; that is, they function to persuade" (Olson, Finnegan and Hope 2008:1). However, the traditional public images were mainly portraits of rulers and religious figures, whereas nowadays digital techniques enable distributing any pictures globally.

\section{Defining visual rhetoric}

During the Antiquity the art of rhetoric was known as the skill to persuade and convince an audience through a public speech. Rhetoricians emphasized the importance to reason logically and to understand emotions of the audience in addition to knowing the subject matter. Aristotle defined rhetoric as the faculty of observing in any given case the available means of persuasion. (Aristoteles, 1997)

Since the development of printing, rhetorical communication gradually changed from spoken to written form. Although reading text is a visual act, the term visual rhetoric refers to artefacts and images used for persuasion. Sonja Foss defines artefacts having a communicative rather than an aesthetic purpose as visual rhetoric. To qualify as visual rhetoric, an image must be symbolic, involve human intervention and to be presented to an audience for the purpose of communicating with the audience. (Foss 2011:141-144) Thus applying visuals for rhetorical purposes is an intentional design action.

In advertisements visual rhetoric is used to persuade people to buy products or services. The selection of visuals and designs is based on marketing research and audience studies. When researching visual rhetoric in outdoor advertisements, the author distinguished three categories of visual rhetoric: brand rhetoric, personalized rhetoric and poetic rhetoric, and their sub-categories (Seliger 2008).

Blair (2004: 42) ponders the relationships among rhetoric, argument and persuasion asking whether an argument can be visual, because arguments are propositions and standardly expressed by sentences in language. He concludes that an argument can readily be visual, but it is not a mere substitute to the written argument: "[...] the visual brings to the argument another dimension entirely. It adds drama and force of a much greater order" (Blair 2004: 59).

\subsection{Vividness of information}

The power of visuals to elicit emotions and to add drama interests psychologists, communication researches and designers. Charles A. Hill writes about the psychology of rhetorical images and introduces the concept of vividness in information (2004: 25-40). Although some psychological studies have confirmed that images tend to elicit more emotional responses and textual messages tend to elicit more analytical responses, Hill (p.30) considers this conclusion too simplistic. Some visual appeals are highly rational, e.g. bar graphs, line graphs and other visuals based on statistical data. Likewise, psychologists have studied readers constructing mental images when reading narrative or descriptive text. The concept of vividness is used to explain the relationship between information and mental images. 
"Vivid information takes the form of concrete and imagistic language, personal narratives, pictures and first-hand experience. [...] Least vivid information is listening or reading abstract, impersonal language and statistics." (p. 31) Hill suggests a comprehensive continuum of vividness (Table 1). According to Hill experiments have demonstrated that vivid information tends to prompt more emotional reactions than non-vivid, abstract information. Vivid information also seems to be more persuasive than non-vivid information.

\begin{tabular}{|l|l|}
\hline \multirow{2}{*}{ Most Vivid Information } & actual experience \\
& moving images with sound \\
static photograph & realistic painting \\
line drawing \\
narrative, descriptive account \\
descriptive account \\
abstract, impersonal analysis \\
statistics \\
\\
\hline
\end{tabular}

Table 1. Vividness of information (Hill 2004:31)

Hill ponders why certain types of assertions tend to have extraordinary persuasive power in a rhetorical situation and instantiate strong emotions in the audience. He argues that this phenomenon seems to be related to visual perception and that many persuasive messages are part of long-term persuasive strategies; the most obvious examples being political and advertising campaigns (p.36).

\section{Persuasion through visual rhetoric}

Advertising has been fast to adopt new technics and media; in 1960s television and photography and in 1990 Internet and new media. Today Internet is a popular platform for commercial advertising and political propaganda, but it is also used to disseminate scientific information.

Vividness of information is high in social media, where anyone can become an advocator by pressing a button. Visual rhetoric and persuasion on-line can cause unexpected outbursts of feelings. Emotions of joy and happiness or disgust and hate are expressed verbally, also when the cause is an image. In following two cases visual rhetoric is used for persuasion in political cartoons and in information design.

\subsection{Political cartoons}

Political cartoons and caricatures are simplified line drawings and situated in the middle of Hill's continuum of vividness. Although meant to be humorous, political cartoons can elicit strong hostile emotions, and even cause prison sentences still today. V.E. Navasky presents in a chronological timeline 20 cases, in which caricatures have caused riots and charges during the 21st century including the consequences caused by the twelve cartoons depicting the prophet Muhammed and published in the Danish newspaper JyllandsPosten and in Internet. 
According to E.H. Gombrich the word and institution of caricature, the playful distortion of a person's face, came about 160os, and presupposes the theoretical discovery of difference between likeness and equivalence. He analyses the famous Charles Philipon's caricature La Poire, a series of drawings, in which King Louise Philippe is depicted as a pear. (1960: 289-291) In caricatures skilful simplifying and distorting makes the point and transfer from portrait to pictorial satire. Gombrich refers to discussions with Ernst Kris, psychoanalysis and art historian: "And just as Freud had looked at verbal wit mainly as an outlet for human aggression, so Kris saw pictorial satire as an instrument for hostile impulses." (1999: 190)

Cartoonists use visual symbols, which carry cultural references and are understood by the readers. Such are national and religious icons - flags, angels and devils. According to Gombrich the devil figure is the most frequently used symbol in satirical prints (1999: 184). Adding visual symbols to a caricature, an artist can express evil qualities, which could not be written or said.

In Finland political cartoon magazines became an important media and a psychological outlet when struggling for independence in 1900-1917. Russian tsar Nicolas 2nd issued a manifesto in 1899, which began the Wave of Russification. Finland was the autonomous Grand Duchy within the Empire of Russia since 1809, and many of the rights promised to Finns were cancelled through the manifesto. Russian became the official language of administration and the press was subject to censorship. Although many magazines were closed down, the number of cartoon magazines increased from 33 issues in 1900 to 288 issues in 1912. Papers were checked in advance and some illustrations censured, because their visual symbols with hidden meanings could strengthen the resistance. (HynninenSeliger 1972)

In Finnish cartoons Finns were drawn as simple country people; women in national dresses and men as peasants in leather boots and round caps. Russian symbols were two-headed eagles and whips with lashes. In 1913 members of Russian royal family visited Finland, and the cartoon magazine Fyren published a drawing depicting a Finnish peasant dancing with a Russian maid servant. The maid had a small comb in her hair, which the censors interpreted as a crown. The artist, Eric Vasström, was sentenced to three months in prison for mocking the Empire of Russia (Ylönen 2001:101).

Since Internet, publishing on-line has become every-man's right. When placing the words political cartoon and a name of a well-known politician in the search engine, it brings hundreds of pictures, caricatures, photographs and video-clips. Because of their high reality-value videos in YouTube gain popularity also in cases they are reworked and remixed. It is almost impossible to censure pictures posted to social media, but the questions of responsible communication and ethics are topical.

The psychological view explains strong emotional reactions caused by political cartoons, but also the visual language is essential. The structure and contents of cartoons and caricatures tend to be relatively simple. Blair (2004: 59) compares visual and verbal arguments: "The visual has the immediacy, a verisimilitude, and a concreteness that help to influence acceptance and that are not available to the verbal." Visual arguments are not dialectical and therefore: "The result is that visual argument tends to be one-sided, presenting the case for or the case against, but not both together." 


\subsection{Information design}

Information graphics, bar-graphs, line graphs and other visuals based on statistics are the least vivid information according to Hill (Table 1). Through information design scientific or numerical data is visualized to explain, persuade and convince people.

Scientists disseminate their findings to the academic community and also to general public. The process may require 'translation', in which visualizations and information graphics are used to explain the research case. Also graphs and diagrams are conceptualized information and the reception is not as immediate as realistic iconic information in photographs and movies.

The phenomenon of climate change is scientifically proved, although it still causes contradictory debates. Already in 1975 scientists had computer models showing that the increase of carbon dioxide $\mathrm{CO}_{2}$ will cause the global temperature to increase with 3 degrees (Flannery 2005, 22). United Nations arranged the first global climate change conference in Rio 1992 and since then politicians and scientists have collaborated to find solutions to the severe problem.

For the general public the complex problem was difficult to understand until 2006 when Al Gore, the former USA vice president, published the book and documentary film The Inconvenient Truth (Al Gore 2006). The film explains the concepts of carbon dioxide footprint and global warming using multimodal approach and the full range of vividness of information. The film gained popularity creating new projects and participatory activities towards sustainability and energy saving. The site of Al Gore (www.algore.com) is active presenting e.g. Climate Solution Strategy, new publications and activities to participate.

\section{Conclusion}

When the art of rhetoric is defined as the skill to persuade by using logical reasoning and understanding the emotions of the audience (Aristoteles, 1997), the task becomes challenging when addressing a global audience. Exaggeration of human features and using national or religious symbols may cause contradictory interpretations. The meanings of symbols are cultural and can elicit strong emotional reactions when placed in unusual context. Video-clips and photographs can be remixed or edited, but still their realityvalue is strong. The target person's position is weak to defend or to complain about the intervention.

Information design has to be based on facts to be credible and therefore exaggerations and distortions are to be avoided. Personal voluntary involvements by well-known persons catch attention and gather followers. Referring to Hill's continuum of vividness, on-line participation can be equivalent to personal experience when people share their stories and co-design events for activism.

The cases exemplifying visual rhetoric in the previous chapters differ, but they have also similarities. They are communicative and symbolic actions, as defined by Foss (p.144), but regarding the third requirement, human intervention, the cases differ. The creator or the designer chooses the visual languages and expressions used to communicate with an audience. Designers creating, selecting and combining visual symbols can make complicated information understandable as well as elicit strong emotions. When a designer cannot know the audience, visual rhetoric is balancing between the freedom to express and cultural understanding. 


\section{References}

Aristoteles (1997) Retoriikka. Runousoppi. Teokset IX. Translation by Paavo Hohti. Explanations by Juha Sihvola. Helsinki: Gaudeamus.

Blair, A.J. (2004) 'The Rhetoric of Visual Arguments' in Hill, C.A. and Helmers, M. (eds.)

Defining Visual Rhetorics. Mahwah, New York: Routledge

Flannery, T. (2005) Ilmastonmuuttujat. [Translation of The Weather Makers.] Helsinki:

Otava.

Foss, S.K. (2005) 'Theory of Visual Rhetoric'. In Smith, K. et al. (eds.) Handbook of Visual Communication. New York: Routledge.

Gombrich, E.H. (1960) Art and Illusion. A Study in the Psychology of Pictorial

Represenation. London: Phaidon.

Gombrich, E.H. (1999) The Use of Images. Studies in the Social Function of Art and Visual Communication. London: Phaidon.

Gore, A. (2006) The Inconvenient Truth. New York: Rodale.

Gronbeck, B.E. (2008) 'Visual Rhetorical Studies. Traces Through Time and Space.' In

Olson, L.C. et al. (eds.) Visual Rhetoric. London: Sage Publications.

Hill, C.A. (2004) 'The Psychology of Rhetorical Images', in Hill, C.A. and Helmers, M. (eds.)

Defining Visual Rhetorics. New York: Routledge.

Hynninen-Seliger (1972) Pilapiirrostutkimus: Taik

Hill, C.A. and Helmers, M. (eds.) (2004) Defining Visual Rhetorics. New York: Routledge.

Jay, M. (1994) Downcast Eyes: The Denigration of Vision in the Twentieth-Century French Thought. Berkeley: University of California Press

Navasky, V.S. (2013) The Art of Controversy. Political Cartoons and Their Enduring Power. New York: Alfred A. Knopf.

Olson, L.C.; Finnegan, C.A. and Hope, D.S. (eds.) (2008) Visual Rhetoric. A Reader in Communication and American Culture. London: Sage Publications.

Seliger, M. (2008) 'Visual Rethoric in Outdoor Advertising' in Undisciplined! DRS Confrence Proceedings. http://shura.shu.ac.uk/id/eprint/49o Sheffield: Sheffield Hallam University. Ylönen, M. (2001) Pilahistoria: Suomi poliittisissa pilapiirroksissa 1800-luvulta 2000-luvulle. Helsinki: SKS. 